Article

\title{
Towards a Characterization of Working Forest Conservation Easements in Georgia, USA
}

\author{
Tyler Reeves ${ }^{1, *}$, Bin Mei ${ }^{1}$, Jacek Siry ${ }^{1}$, Pete Bettinger ${ }^{1}\left[\right.$ and Susana Ferreira ${ }^{2}$ \\ 1 Daniel B. Warnell School of Forestry and Natural Resources, University of Georgia, Athens, GA 30602, USA; \\ bmei@uga.edu (B.M.); jsiry@uga.edu (J.S.); pbettinger@warnell.uga.edu (P.B.) \\ 2 Department of Agricultural \& Applied Economics, University of Georgia, Athens, GA 30602, USA; \\ sferreir@uga.edu \\ * Correspondence: tgr54347@uga.edu; Tel.: +1-478-414-6347
}

Received: 22 April 2020; Accepted: 2 June 2020; Published: 4 June 2020

\begin{abstract}
We examine the attributes of working forest conservation easements in Georgia. Easement contracts and baseline reports are inspected to investigate easement themes, land use types, recreation opportunities, hydrological features, and forest management activity. Easement themes are heavily weighted towards themes of protecting natural habitat and preserving the conservation values of properties. Predominant land use types include wildlife food plots, bottomland hardwoods, and planted pine stands. Common hydrological features found were small creeks/streams and ponds. Lastly, forest management was characterized as having small amounts of restrictions present, with forest management being largely similar to other unencumbered property in the southeastern USA. This information can be used as a reference for landowners interested in establishing a working forest conservation easement (WFCE) on their property as well as a tool for comparison for researchers investigating easement characteristics in other regions.
\end{abstract}

Keywords: ecosystem services; forest management; land use; property restriction; recreation

\section{Introduction}

Georgia has over 24 million acres of commercially-available timberland, more than any other state in the United States (USA) [1]. This forest resource is a valuable stock of natural capital to Georgia's economy, providing wood and fiber inputs as well as other nonmarket ecosystem services such as carbon sequestration, water purification, and recreational opportunities. The total annual market impact of the forest industry in Georgia from 2018 was estimated at around $\$ 36.3$ billion [2]. Similarly, a study by Moore et al. [3] estimated the nontimber and nonrecreation ecosystem service value of forestland in Georgia to be even greater at $\$ 37.6$ billion per year.

Despite the economic importance of Georgia's forestland, the commercial nature of forest resources and, to some extent, the provision of other ecosystem services, are under threat as increasing amounts of land are being converted to development. Urbanization is the largest reason for forest conversion to nonforest uses in Georgia [1]. This development trend is not limited to Georgia, as Wear and Greis [4] estimated a South-wide rate of land development to urban area between 1 and 1.4 million acres per year from 1997-2060. While forest conversion may be profitable from a private landowner standpoint, it may result in socially inefficient outcomes once nonmarket ecosystem services, which have the characteristics of public goods, are considered. Lacking mechanisms that compensate forest owners for the provision of public goods, as development values continue to rise and outpace the value of timber production, subsequent land parcelization [5] and a reduction in overall levels of public goods are likely. This is predicted to result in greater amounts of forest loss and fragmentation [6]. 
Parcels enrolled in conservation easements (CEs) are one potential method to halt or slow down conversion of forests to other uses. CEs are a legal contract between a landowner and a land conservation agency that restrict the use of a parcel to promote its conservation values [7]. CEs generally permanently restrict the development potential of a parcel to maintain the property in its current use. The owner of the property typically maintains ownership, donating only the right to development. One form of easement that is particularly tailored towards protecting forestland is a working forest conservation easement (WFCE), which are forestry-focused conservation easements that generally allow some form of timber harvesting on site. They are especially beneficial for their effect on property taxes.

Historically, Georgia possesses one of the highest property tax rates on forestland property in the southeastern USA [8,9], making it more difficult for forestland owners to keep their land intact [10,11]. WFCEs help alleviate this property tax pressure by reducing the underlying value of the property. With a reduced property value, the associated property taxes are decreased. This helps reduce the burden on forestland owners, while still allowing forest management practices [12]. The tax benefits of WFCEs are not limited to reduced annual property taxes. When landowners enroll their property in a WFCE they may also receive a federal tax deduction as well. By enrolling land in a WFCE, property owners receive a federal tax deduction equal to the loss in fair market value of the property. The loss in fair market value is equal to the difference between the appraised value of the property before and after the development rights are restricted. Landowners may apply this deduction on up to $50 \%$ of their annual gross income for the year of the donation and up to 15 years in the future until the value of the deduction is exhausted [7]. In addition to the tax benefits, because landowners voluntarily enroll their property in WFCEs, they avoid many of the potentially contentious issues of public land acquisition [13]. Conservation organizations also favor this land protection mechanism as it provides a more financially attractive means of conserving land. The cost of purchasing an easement is generally much lower than fee-simple acquisition [14].

The benefits of CEs have resulted in a boom in their use. While CEs have been utilized to protect scenic areas and parks in the USA since the late 1800s, their first statutory use was in Massachusetts in 1956 and California in 1959. However, the vast majority of easements have been established within the past 40 years, coinciding with the passage of the Uniform Conservation Easement Act in 1981 [15,16]. In 1980, the area protected under CE in the USA was around 128,000 acres [17]. By 2015, this number had risen to over 16.78 million acres [18]. Currently, the National Conservation Easement Database reports there are approximately 2 million acres of easements with the explicit purpose of conserving forests in the USA [19]. This value is likely an underestimate given that CEs are shown to have multiple uses in this investigation. Therefore, CEs are likely to satisfy multiple conservation objectives such as preserving wildlife habitat while also maintaining forests as a land use.

Despite their popularity, easements can have unintended consequences. One of the primary issues with CEs is their distributional and equity implications. CEs benefit donors by lowering the property taxes on site. However, research suggests properties close to easements may receive a property value premium associated with their proximity [20-22]. As neighboring properties increase in value, owners can capitalize the gains if they sell the property, but otherwise would be subject to higher property taxes. Additionally, easements located in fragmented landscapes with limited connectivity may result in inefficient conservation outcomes. Select wildlife species may require large habitat ranges or connected dispersal routes to breed. Enrolling land in a CE with the purpose of preserving wildlife may fall short in these areas of fragmented conservation [23]. Thus, it is necessary to consider land-market and ecological dynamics in future land use planning when determining conservation outcomes for CE enrollment.

Many easements are enacted with the help of large public conservation organizations such as The Nature Conservancy, Land Trust Alliance, or The Conservation Fund. These organizations understandably seek to disclose their conservation success stories. However, these easements only represent a fraction of the total land enrolled in CE programs. Numerous other properties are enrolled in easements with the help of smaller land trusts or agencies that do not always publicly 
disclose the contents of their contracts or location of properties. As such, there is often a lack of understanding about the types of landscapes being preserved and the associated allowances and restrictions $[13,24,25]$. Further, there is a lack of research on the type of forest management that goes on in CEs [26]. Most previous research in this area has relied on surveys of property owners to determine potential forest management activities [27]. Additional research examining the actual easement documents along with baseline property reports is needed.

To this end, the objective of this paper is to provide a characterization of WFCEs in Georgia. The WFCEs examined in this study represent a combination of easements from both large, industrial landowners as well as small-scale family forest owners. These easements were also taken from both state and private conservation group databases so that they can be considered a diverse sample of properties that may be established under a WFCE in Georgia. In establishing this characterization, we examine easement structure and language to determine key concepts, select attributes, and permitted/prohibited activities. Combining these, we aim to provide a working guide of WFCEs in Georgia that can be potentially used by landowners, conservation groups, and/or federal agencies.

\section{Materials and Methods}

\subsection{Data}

We examined WFCEs throughout the state of Georgia. Information consisted of easement contracts and baseline property reports. The names, locations, and baseline property reports were provided by the Georgia Forestry Commission, Georgia Department of Natural Resources, and Georgia-Alabama Land Trust. Additional information on baseline reports was obtained from the Georgia Building, Land, and Lease Inventory of Property database [28]. These were matched to easement contracts purchased online through the Georgia Clerk's Authority website [29].

While not identical for all easements, easement contracts had five primary sections. These were: (1) a declaration of the conservation objectives achieved by the property, (2) a description of the easement and surrounding area, (3) an outline of the easement purpose and target elements, (4) a listing of the use limitations, and (5) an explanation of the easement grantor's reserved rights. Baseline reports contained similar elements as easement contracts, but tended to provide more detailed depictions of property composition. Property composition was characterized using a combination of land use type descriptions and site visit photographs. Photographs were provided to document the presence of land use types, important habitat areas, or historical features. Generally, these photographs comprised around $60 \%-70 \%$ of the total length of baseline reports. Reports varied in size from 48 to 202 pages, with most reports falling in a range of between 70 and 80 pages.

A total of 86 WFCEs were identified from our three easement sources. These organizations provided easements that had a significant forest conservation component. This list should not be considered an exhaustive collection of all the WFCEs in Georgia. Rather, it is meant to provide a collection of easements that are likely to represent WFCEs throughout the state. Several key areas were analyzed as part of this investigation. These were: easement themes, land use types, recreational uses, hydrological features, and forest management activity. Easement contracts contained sections specifically outlining easement purpose(s), permitted and prohibited forestry practices, available recreation opportunities, and hydrological features. Land use types were included to provide an overview of the land use types most frequently conserved under this easement type.

The years of establishment for WFCEs ranged from 2002 to 2018. The average number of WFCEs established annually increased slightly during this period at around 0.4 additional easements per year. While this sample only represents a subset of easements in Georgia, this increase could be reflective of the pattern of increasing easement utilization over time [18]. WFCE size also varied considerably, ranging from 59 to 5,285 acres. To accommodate this variability, easement size was split into three categories: (1) less than 500 acres, (2) 500-1000 acres, and (3) greater than 1000 acres. As mentioned earlier, these easements should not be considered an exhaustive list. Easements 
established by other land trusts or agencies before easements in this database may contain different characteristics. A summary table of easement classification is provided in Table 1.

Table 1. Descriptive statistics of 86 working forest conservation easements (WFCEs) in Georgia.

\begin{tabular}{ccccccc}
\hline $\begin{array}{c}\text { Size } \\
\text { Category }\end{array}$ & Count & Total Acres & Average & Minimum & Maximum & $\begin{array}{c}\text { Standard } \\
\text { Deviation }\end{array}$ \\
\hline$<500$ & 35 & 9046.50 & 258.47 & 59.00 & 460.00 & 126.70 \\
$500-1000$ & 22 & $15,976.00$ & 726.18 & 506.00 & 987.00 & 169.91 \\
$>1000$ & 29 & $74,217.00$ & 2559.21 & $1,009.00$ & 5285.00 & 1409.03 \\
Grand Total & 86 & $99,239.50$ & 1153.95 & 59.00 & 5285.00 & 1311.05 \\
\hline
\end{tabular}

Lastly, the physiographic region in which WFCEs were located was included. Most easements were in the southern portion of the state, with 52.33\% in the Southeastern Plains and $22.09 \%$ in the Southern Coastal Plain region. These regions correspond to the GA_2 TimberMart-South region. TimberMart-South (TMS) is a price reporting service for stumpage and delivered wood prices in the southeastern, USA (TMS also provides other forestry business information and publishes quarterly and annual reports for a variety of clients in the forest sector). The stronger timber markets of GA_2 may partially explain the higher level of WFCEs in this region than in the more northern GA_1 region comprised of the Piedmont, Ridge and Valley, and Blue Ridge regions [30]. WFCEs in this region (GA_1) were relatively rare with only a combined $25 \%$ of the 86 easements occurring here. A map of the easement locations in Georgia is displayed in Figure 1.

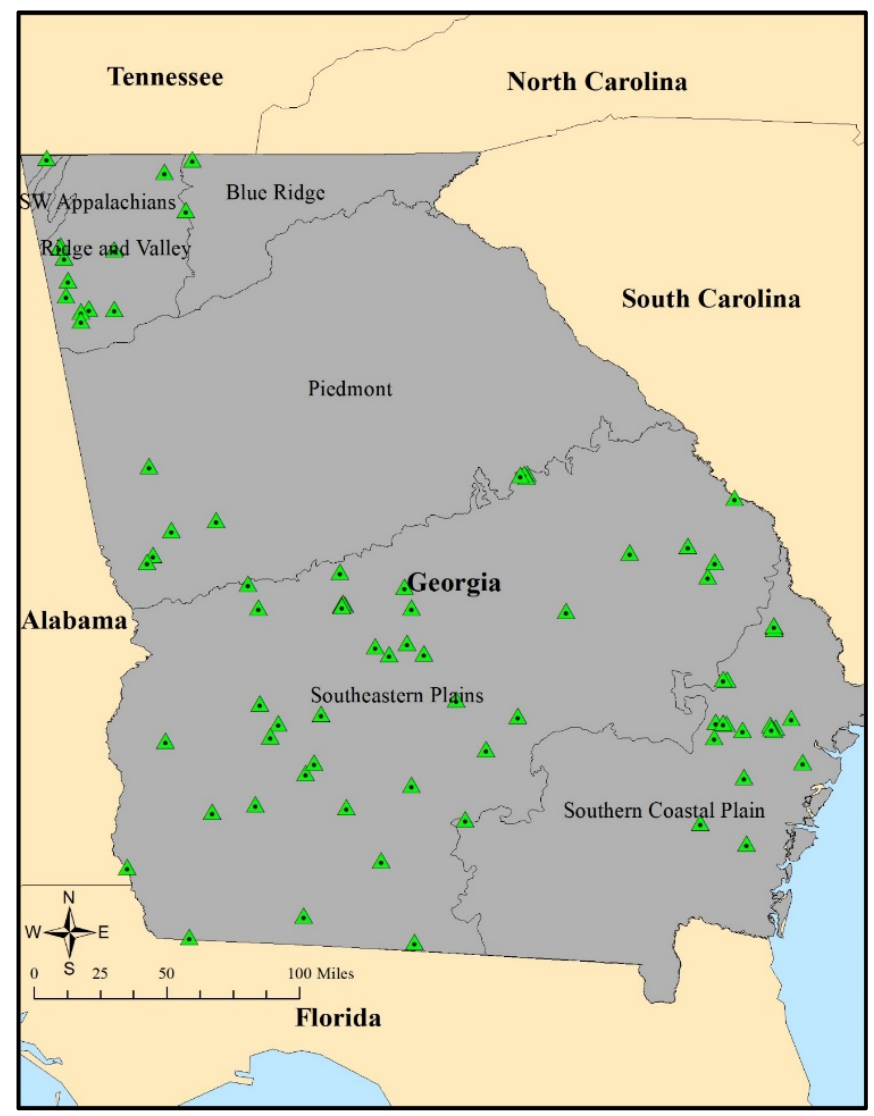

Figure 1. Map of Georgia with easement locations of WFCEs identified in this study. 


\subsection{Methodology}

Easement contracts were downloaded in a PDF format. These PDFs were combined with the baseline data reports to create a consolidated document for each easement. Nonsearchable information such as pictures and signature pages were removed to reduce PDF conversion time. Easement contracts were then converted to searchable text using Optical Character Recognition in Adobe Pro software. This allowed searching for particular words and/or phrases within the documents. However, many documents contained extraneous markings such as signatures, handwritten dates, and government stamps from the easement contracts sections that interfered with the document image quality. Therefore, the contracts were converted into word processing software for proofing. Each easement contract was proofed for mistakes generated in the Optical Character Recognition process. Once proofed, documents were loaded into Microsoft Excel for easy importing. From here, documents were imported into R statistical software. Finally, a combination of the R package Tidytext and Excel were used to search for particular words and phrases [31].

\subsubsection{Easement Themes}

To identify the goals of WFCEs, themes of easement contracts were examined. Following Mortimer et al. [27], themes consisted of stated purposes listed in the contract, as well as select easement elements. Stated purposes were generally given in a "purpose" or "goals" section of the easement contract. These included goals related to protecting natural habitat, conservation values, endangered/threatened species, animal migration routes, or habitat connectivity. Easement contracts contained specific language indicating if a property protected "endangered/threatened species". No further interpretation of classifying wildlife in this category was made by the authors.

Elements of easement contracts were often given in a separate "target elements" section. These included: enhancing scenic quality, maintaining soil productivity, meeting the requirements for a Georgia Wildlife Conservation Strategy priority habitat, preserving historical features, or providing public access. Listing as a Georgia Comprehensive Wildlife Conservation Strategy site indicated the property protected at-risk species, high priority habitats, or high priority waters as identified by the Georgia Department of Resources Wildlife Resources Division [32]. To avoid overlap, the purposes and elements were consolidated into the top 10 themes. Easement elements had a large degree of variability depending on the grantor and grantee's objectives, the region, and characteristics present. To account for this, easement elements of a similar nature were grouped together. This refers primarily to consolidating hydrologic and wildlife habitat themes. Elements with similar phrasing, such as "protecting wetland areas" or "protecting river corridors", were grouped into a single theme "protecting hydrologic habitat". Likewise, easement reports with provisions for protecting specific endangered or threatened species were merged into the "protecting endangered/threatened species" theme. While the elements "protecting endangered/threatened species" and "Georgia Comprehensive Wildlife Conservation Strategy site" both pertain to wildlife habitat, the two were distinguished to include the difference between protection of actual wildlife species and the potential for wildlife habitat protection.

\subsubsection{Land Use Types}

To provide coverage of what land uses are conserved most frequently, land use types under WFCE contracts were examined. Land use delineations were taken directly from baseline property reports. Land use types were reported either as a percentage of total easement area or simply as being present on site. There were nine different land use types reported: (1) bottomland hardwoods, (2) mesic/upland hardwoods, (3) mixed pine/hardwood, (4) natural pine, (5) planted pine, (6) fields/pasture, (7) planted wildlife food plots, (8) evergreen hammocks, and (9) bogs/limesinks, which are defined below.

1. Bottomland hardwood $(\mathrm{BH})$ areas were classified as locations where soil is periodically inundated by water during several parts of the year. Common tree species included baldcypress 
(Taxodium distichum), several gum species (Nyssa spp.), and river birch (Betula nigra). These forests provide crucial ecosystem services such as greenhouse gas mitigation, reducing flood severity and risk, enhancing water quality, and reducing the amount of sediment entering waterways $[33,34]$. The extent of these forests has been significantly reduced from their historical occurrence across the southeastern USA, mainly due to conversion of these areas to cropland uses [35,36].

2. Mesic/upland hardwoods (MH) were classified as areas with moist to xeric soil types dominated by many species of oak (Quercus spp.), hickory (Carya spp.), and beech (Fagus spp.) [37]. This forest type provides critical wildlife forage habitat, a diversity of forest products, and multiple forest management opportunities [38,39].

3. Mixed pine/hardwood (MIX) land use consisted of an assemblage of mixed pine and hardwood stands. Within this forest type, select sites were characterized as primarily pine with some hardwood understory, or predominantly hardwoods with pines interspersed throughout the stand.

4. Natural pine (NP) land use consisted of typically xeric, sandier sites with tree species consisting of nonplanted longleaf (Pinus palustris), slash (Pinus elliottii), or loblolly pine (Pinus taeda). Natural pine areas have decreased dramatically in the past three decades with 9.3 million acres of this forest type present in 1972 compared to around 4.1 million acres today [1,40].

5. Planted pine (PP) areas were locations in which pine species had been either hand or machine planted. Typically, this forest type was where most forest management activity was present.

6. Fields/pasture (FP) lands consisted of open areas that were used primarily for livestock grazing, abandoned agricultural fields, or power line right-of-ways.

7. Wildlife food plots (WFP) were areas planted with native grasses or crops to be used primarily as forage areas for wildlife species. They were primarily used as a supplement to hunting activity on easement sites. These areas are typically small openings within or along forest stands.

8. Evergreen hammocks (EH) were classified as small upland areas surrounded by wetlands or floodplains where fire is generally excluded. Common canopy species include submesic oaks, magnolia species (Magnolia spp.), and American holly (Ilex opaca). These areas are critical for conservation due to their threatened status from increasing fragmentation and conversion to agriculture or development.

9. Lastly, bogs/limesinks (BL) consisted of depressional wetlands that often form in grassy savanna areas dominated by evergreen shrubs, sedges, and rushes. These areas are often critical habitat for many species of reptiles, amphibians, and plants that are adapted to these habitat conditions to survive $[41,42]$.

Mesic and upland hardwoods were occasionally separated into two distinct land use types on select easement documents. Due to their similarity, they were consolidated into a single land use category for this investigation. A cross-tabulation on easement themes by land use type was performed to determine the relationship between land use and conservation emphasis. Abbreviations $(\mathrm{BH}, \mathrm{MH}$, $\ldots$, BL) are listed for use in Table 2.

Table 2. Cross-tabulation of easement themes by land use types based on 86 WFCEs in Georgia.

\begin{tabular}{|c|c|c|c|c|c|c|c|c|c|c|}
\hline & $\begin{array}{c}\text { WFP } \\
\%\end{array}$ & $\begin{array}{c}\text { BH } \\
\%\end{array}$ & PP \% & $\underset{\%}{\operatorname{MIX}}$ & $\begin{array}{l}\text { FP } \\
\%\end{array}$ & MH \% & NP \% & $\begin{array}{l}\text { BL } \\
\%\end{array}$ & $\begin{array}{c}\text { EH } \\
\%\end{array}$ & $\begin{array}{c}\text { Theme } \\
\text { Total }\end{array}$ \\
\hline Natural Habitat & 93.59 & 93.42 & 92.75 & 95.38 & 100.00 & 96.30 & 95.35 & 100.00 & 100.00 & 81 \\
\hline Conservation Values & 91.03 & 89.47 & 91.30 & 89.23 & 90.74 & 90.74 & 90.70 & 92.31 & 92.86 & 78 \\
\hline Hydrologic Habitat & 88.46 & 100.00 & 89.86 & 89.23 & 85.19 & 87.04 & 86.05 & 92.31 & 100.00 & 76 \\
\hline Endangered or Threatened Species & 29.49 & 34.21 & 28.99 & 40.00 & 35.19 & 25.93 & 30.23 & 30.77 & 28.57 & 75 \\
\hline Enhance Scenic Quality & 50.00 & 51.32 & 50.72 & 55.38 & 53.70 & 51.85 & 41.86 & 50.00 & 50.00 & 45 \\
\hline Soil Productivity & 88.46 & 88.16 & 86.96 & 84.62 & 94.44 & 85.19 & 83.72 & 84.62 & 85.71 & 38 \\
\hline GCWCS & 28.21 & 31.58 & 24.64 & 32.31 & 22.22 & 29.63 & 32.56 & 26.92 & 21.43 & 29 \\
\hline Protect Historic Features & 33.33 & 34.21 & 36.23 & 32.31 & 42.59 & 37.04 & 30.23 & 50.00 & 57.14 & 24 \\
\hline Enhance Connectivity & 19.23 & 19.74 & 17.39 & 21.54 & 20.37 & 22.22 & 23.26 & 30.77 & 35.71 & 16 \\
\hline Public Access & 3.85 & 3.95 & 4.35 & 4.62 & 0.00 & 3.70 & 6.98 & 3.85 & 0.00 & 3 \\
\hline Land Use Type Total & 78 & 76 & 69 & 65 & 54 & 54 & 43 & 26 & 14 & - \\
\hline
\end{tabular}




\subsubsection{Recreational Opportunities}

Each WFCE was examined for the reserved recreational rights stated in the easement contract. While not guaranteeing each recreational activity was generally performed, contract language permitted the properties be used for each of seven recreational activities: hunting, fishing, hiking, camping, horseback riding, all-terrain vehicle use, and watersports. Regarding all-terrain vehicle use, most easement contracts stipulated the property not be used as a "commercial" all-terrain vehicle facility. However, they generally allowed for their "recreational" use if they did not significantly increase erosion or reduce the conservation value of the property.

\subsubsection{Hydrologic Features}

Each WFCE was examined for potential hydrological features. These features were included to account for the increasing importance of forest conservation on water quality [43]. Four hydrologic features were identified: (1) ponds, (2) lakes (hydrologic feature classification was taken directly from baseline data reports; the authors did not seek to classify water features as a pond or lake by some size threshold), (3) creeks/streams (creeks and streams were combined into a single category due to their interchanged use in easement documents), and (4) rivers. To be marked for inclusion, each feature was required to be physically present on site. This distinction was used to draw separation from areas that may have been included in specific watersheds of rivers or creeks, but did not possess river/creek frontage on the property. Another cross-tabulation was performed to determine the relationship between hydrologic features and the potential for recreation on WFCEs and is shown in Table 3.

Table 3. Cross-tabulation of recreational activities by hydrological features based on 86 working forest conservation easements in Georgia.

\begin{tabular}{cccccc}
\hline Recreation & Pond & Lake & Creek/Stream & River & Activity Total \\
\hline Hunting & $100.00 \%$ & $100.00 \%$ & $98.80 \%$ & $100.00 \%$ & 85 \\
Fishing & $100.00 \%$ & $100.00 \%$ & $98.80 \%$ & $100.00 \%$ & 85 \\
Camping & $100.00 \%$ & $100.00 \%$ & $98.80 \%$ & $100.00 \%$ & 85 \\
Hiking & $100.00 \%$ & $100.00 \%$ & $97.59 \%$ & $100.00 \%$ & 84 \\
All-Terrain Vehicle & $93.88 \%$ & $100.00 \%$ & $91.57 \%$ & $82.35 \%$ & 79 \\
Horseback Riding & $91.84 \%$ & $90.91 \%$ & $89.16 \%$ & $76.47 \%$ & 77 \\
Watersports & $65.31 \%$ & $54.55 \%$ & $50.60 \%$ & $70.59 \%$ & 43 \\
Feature Total & 49 & 11 & 83 & 17 & - \\
\hline
\end{tabular}

\subsubsection{Forest Management}

The scope of forest management on WFCEs was also examined. This included information regarding forest management plans and permitted/restricted activities. Sections regarding forest management plans examined easement contracts for the presence of forest management plans, specific requirements, and duration. Forest management plans within the context of a WFCE can be considered a set of guidelines that help landowners incorporate conservation principles while ensuring that forest management activities are performed within the guidelines of easement restrictions [44]. In addition, plans were filtered to document whether a plan was required to be composed by a registered forester or wildlife biologist. Lastly, the duration of forest management plans was examined. This information stipulated how frequently the management plans required revision. Permitted activities considered the types of forest management activity allowed on site. Lastly, restricted activities were mainly concerned with limitations on forest management activity type or harvest areas. This supported clarifying the extent of forest management generally performed on WFCEs.

To gain a sense of the overall restrictiveness of WFCEs, we generated a harvestable area restriction scale. The restriction scale had five different grades: (1) no additional, (2) mild, (3) marginal, (4) moderate, and (5) severe restriction. The grades were based on the percentage of nonharvestable special natural areas, i.e., locations with significant naturally occurring ecosystems, from which 
harvesting or management is severely limited [45]. A grade 1 restriction had no area designated as a special natural and required only that best management practices for forestry be practiced (all easement documents required the owner to follow best management practices for any forest management performed on site; best management practices are guidelines concerning silvicultural activities to reduce the impact of nonpoint source and thermal pollution [46]. A grade 2 restriction corresponded to a no-harvest area of between $0 \%$ and $25 \%$ of total easement area. Similarly, grade 3 restrictions corresponded to a no-harvest area of between $25 \%$ and $50 \%$, and grades 4 and 5 comprised no harvest areas of $50 \%-75 \%$ and greater than $75 \%$, respectively. As with previous sections, another cross-tabulation between forest management restrictions and easement size categories was performed to determine the potential relationship between parcel size and level of restriction.

\section{Results}

Several themes were common to the majority of the WFCEs. These themes and their prevalence are depicted in Figure 2. Top themes included preserving natural habitat, protecting conservation values, protecting hydrologic habitat, and protecting endangered/threatened species such as the gopher tortoise (Gopherus polyphemus) or highscale shiner (Notropis hypsilepis). These four themes were present on over $85 \%$ of all WFCEs. The themes of enhancing scenic quality, maintaining soil productivity, listing as an area for the Georgia Comprehensive Wildlife Conservation Strategy, protecting migration routes for species such as the Swainson's warbler (Limnothlypis swainsonii), prohibiting fragmentation, and preserving historical resources such as historical buildings, cemeteries, and battlegrounds were also common, occurring on between $25 \%$ and 50\% of all WFCEs. Enhancing habitat connectivity was less prevalent, occurring on less than $25 \%$ of all WFCEs. This often took the form of WFCEs connecting areas to larger state parks or Forest Legacy areas. Lastly, providing public access was the least common theme, only occurring on around $3 \%$ of easement contracts.

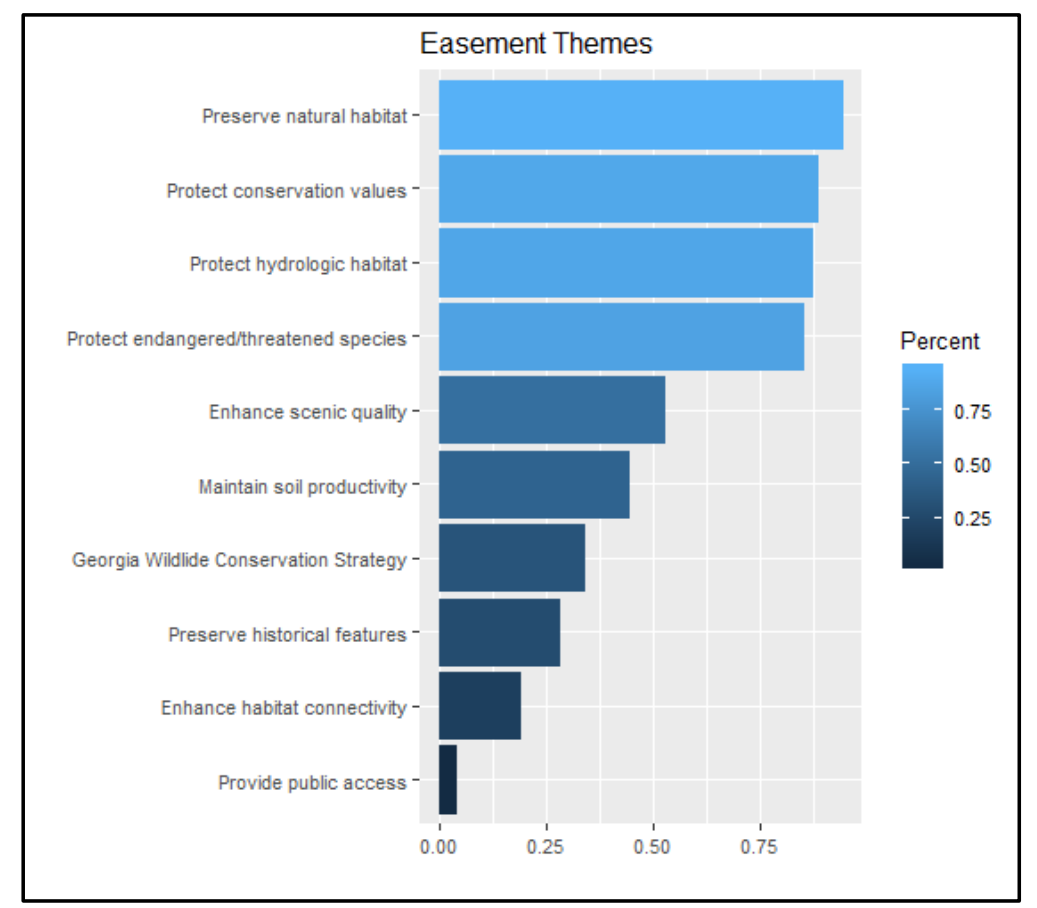

Figure 2. Listing of easement themes by their prevalence based on a total number of 86 WFCES in Georgia. 


\subsection{Land Use Types}

The most frequent land use type found was wildlife food plots (this refers to most frequent in terms of number of easements possessing this land use type; this does not imply that this land use type comprised the largest area). This land use type was present on over $90 \%$ of the WFCEs investigated. Given that all but one WFCE allowed hunting on site, this result was unsurprising. Other common land use types present were bottomland hardwoods, planted pines, and mixed pine/hardwoods. These land use types were present on over $75 \%$ of all WFCEs observed. Specifically, all land use types excluding bogs/sinks and evergreen hammocks were present on more than $50 \%$ of all WFCEs. These particular land use types are relatively uncommon throughout the landscape in this study.

Regarding the relationship between land use type and easement theme, the relationship tended to follow the theme prevalence among all easements with a few minor exceptions. The values shown in Table 2 can be interpreted as, "among easements with this land use type present, the corresponding theme is present on X percentage of these sites." Generally, the themes that occurred with the greatest frequency were present in relatively the same proportions among land use types. Two exceptions are the themes of endangered/threatened species protection and soil productivity. For the endangered/threatened theme, this theme was found on $87 \%$ of all WFCEs but occurs concurrently among all land use types between $30 \%$ and $40 \%$ of the time. Conversely, the theme of soil productivity was only present on $44 \%$ of all WFCEs, but the concurrence of this theme with all land use types was between $80 \%$ and $90 \%$ on average.

\subsection{Recreational Activities}

The availability of recreational opportunities was relatively standardized across most of the WFCEs in the study. Generally, easement texts contained a phrase allowing for several different types of recreation on site. As a result, most easements allowed many of the recreational opportunities investigated. Hunting, fishing, hiking, camping, all-terrain vehicle use, and horseback riding were permissible on $90 \%$ or more of all WFCEs observed. Watersports were less common, but still permissible on $50 \%$ of the WFCEs. This is likely a function of not all WFCEs having suitable areas for this form of recreation.

\subsection{Hydrological Features}

The most frequently encountered hydrological feature was creeks/streams. These features were present on over $96 \%$ of all WFCEs. This high percentage of creeks and streams related to the relative abundance of the bottomland hardwood land use type. Ponds were also common on many WFCEs. Rivers and lakes were encountered less frequently. WFCEs were much more likely to have a creek or stream that was part of a larger river's watershed or flowed into/from the river several miles up/downstream. Likewise, smaller ponds that were used for wildlife habitat or fishing purposes were more common than larger lakes.

For the relation of recreation to hydrological features, the relationship also largely followed the prevalence of available recreation opportunities. Because most forms of recreation were available across all sites, the proportion of available recreation by hydrological feature was relatively constant across hydrological features. As mentioned earlier, watersports were the least common activity, and it was postulated to be a result of a lack of suitable surface water areas. From the cross-tabulation shown in Table 3, we saw this relation appear to hold. Where ponds and rivers are present, watersports are available on at least $65 \%$ of these sites. However, for sites with smaller hydrological features such as creeks or streams, this rate is lower at approximately $50 \%$ of sites. WFCEs with lakes present had a relatively low frequency of watersport availability $(\sim 55 \%)$; however, this may relate to the small number of easements possessing this hydrological feature $(\sim 13 \%)$. 


\subsection{Forest Management}

Easement documents were assessed for forest management characteristics in the form of forest management plans, permissible activities, and restricted activities. Of the 86 easements examined, $97 \%$ had a forest management plan in place. The overwhelming majority $(95 \%)$ also required the forest management plan be written by a registered forester or certified wildlife biologist. Generally, if a forest management plan was not in place, timber harvesting was restricted to only selection cutting. Forest plan durations were listed four discrete categories: (1) 5 years, (2) 10 years, (3) 15 years, and (4) unlisted duration.

Permitted forest management activities were also examined as part of this investigation. Activities pertained to allowable harvest types and silvicultural operations. Harvest types included clearcutting and selection cutting. Silvicultural operations included permissibility of thinning, chemical use (herbicide/fertilizer), invasive species removal, and prescribed burning. Out of 86 easements, approximately $92 \%$ allowed clearcutting as a harvest option. Among these, several properties restricted the size of clearcuts to an acreage limit or percentage of total area. This is discussed further in the forest management restrictions section below. Selection cutting was practiced on approximately $98 \%$ of easements. Given that selection cutting is considered significantly less intensive, it is unsurprising that the proportion of WFCEs with this provision is permitted.

Other forest management activities examined were mainly concerned with silvicultural practices that would be commonly encountered on typical southern timber operations. Exotic/invasive removal was the most commonly performed activity. All but one easement allowed this practice. Nearly all the WFCEs examined allowed most of the listed forms of silvicultural practices with each present on over $90 \%$ of the easements. A summary of forest management plans along with permitted activity is provided in Table 4.

Table 4. Characteristics of forest management activity based on 86 WFCEs in Georgia.

\begin{tabular}{cccccc}
\hline Forest Management Plan & Number & $\mathbf{\%}$ & Activity & Number & $\%$ \\
\hline Present & 83 & 96.51 & Clearcut & 79 & 91.86 \\
Registered Forester/Biologist & 82 & 95.35 & Selective Harvesting & 84 & 97.67 \\
5-Year Plan & 5 & 5.81 & Prescribed Burning & 82 & 95.35 \\
10-Year Plan & 7 & 8.14 & Thinning & 84 & 97.67 \\
15-Year Plan & 36 & 41.86 & Herbicide/Fertilizer & 78 & 90.70 \\
Unlisted & 38 & 44.19 & Exotic/Invasive removal & 85 & 98.84 \\
\hline
\end{tabular}

The level and type of forest management restrictions present on WFCEs were also examined. Restrictions were listed as: the outright prohibition of clearcutting, the inability to harvest in select special natural areas, limits to the size of clearcut areas, or restrictions on residual basal area after harvesting. The inclusion of clearcut prohibitions required a direct statement in the easement contract regarding the exclusion of this harvest type. Language indicating the prohibition of "large clearcuts" was classified as a clearcut size restriction. The most common restriction was the inability to harvest in a special natural area or no harvest area. Approximately $87 \%$ (75 out of 86 ) of the total WFCEs had this restriction present. Other restrictions were far less frequent. Restricting harvesting to forest management only areas was present on only $40 \%$ (34 out of 86 ) of easements, with clearcut size restrictions found on $29 \%$ (25 out of 86 ). Clearcut prohibition and residual basal area requirements were relatively rare, occurring on $8 \%$ and $7 \%$ (seven and six out of 86 ) of WFCEs, respectively.

In terms of restricted area, the majority of WFCEs fell into the categories of mild to moderate restriction (Grades 2 and 3). Easements with no restrictions on harvest area were relatively rare at only $15 \%$. Likewise, only about $12 \%$ of the WFCEs had restrictions on greater than $50 \%$ of total easement area. This indicates that some restrictions on harvestable area of WFCEs are common. However, they will likely be relatively minor in terms of total operable area. Table 5 shows the type of restrictions present as well as the associated grades of restriction. 
Table 5. Management restrictions and their relative frequency based on 86 WFCEs in Georgia.

\begin{tabular}{ccccc}
\hline Restriction & $<\mathbf{5 0 0}$ & $\mathbf{5 0 0 - 1 0 0 0}$ & $\mathbf{> 1 0 0 0}$ & Total \\
\hline Special Natural Area & 28 & 20 & $\mathbf{2 7}$ & $\mathbf{7 5}$ \\
Special Natural Area (Average \%) & $19.54 \%$ & $31.20 \%$ & $\mathbf{2 0 . 8 8 \%}$ & $26.30 \%$ \\
Forestry Only Area & 15 & 7 & 12 & 34 \\
Clearcut Size Restriction & 9 & 8 & 8 & 25 \\
Clearcut Prohibition & 5 & 0 & 2 & 7 \\
Residual Basal Area & 2 & 3 & 1 & 6 \\
Grade 1 & 8 & 2 & 3 & 13 \\
Grade 2 & 16 & 11 & 14 & 41 \\
Grade 3 & 6 & 4 & 12 & 22 \\
Grade 4 & 5 & 1 & 0 & 6 \\
Grade 5 & 0 & 4 & 0 & 4 \\
\hline Total & 35 & 22 & 29 & 86
\end{tabular}

Regarding forest management restrictions and WFCE category, there were a few interesting patterns. The percentage of special natural areas restricted was relatively constant across all size classes, generally between $20 \%$ and $30 \%$ with an overall percentage of $26 \%$. The restrictions of forestry only areas, clearcut size restrictions, clearcut prohibitions, and residual basal area requirements were relatively evenly split among the size categories. The same was generally true of the harvest grade restrictions. This would seem to indicate that restrictions do not appear to be greatly affected by the size of the WFCE (ANOVA analyses were performed to test for potential effects of size classes on forest management restrictions. All restrictions excepting the Grade 5 restriction did not vary significantly by size category. However, due to the small number of WFCEs in this category, the power of the test is low and we do not place much confidence in its inference).

\section{Discussion}

Many of the findings of this study suggest some general patterns that may be present on WFCEs in Georgia and potentially throughout the southeastern USA. Certain elements are much more common than others. These can largely be inferred from a simple analysis of the relative frequencies throughout the WFCEs. Several predominant themes of WFCEs were readily apparent. Overall, this helps clarify ambiguities regarding management practices and conserved land use types on WFCEs.

Easement themes were heavily structured towards themes of habitat protection and preservation. Emphasis was given to maintaining natural land uses and protecting critical habitat, which suggests the large potential of these operations to provide public goods. Consequently, most easements could dually be considered for wildlife protection despite being structured for forestland use. In addition, themes of hydrological protection were greatly emphasized. This likely relates to the prevalence of riparian habitats protected under these easement types. While habitat protection and preservation were stressed, themes of historical preservation, habitat connectivity, and public access were given less importance. Sites with historical preservation themes frequently had some form of historical graveyard, markers, or homesites located on the property. This does not likely preclude the importance of these features for conservation, but rather highlights their uniqueness in the landscape.

Habitat connectivity may have not been ranked as highly due to most easements being located in the southern portion of the state, where agricultural and rural areas are more common. Habitat connectivity is likely to be less problematic in these areas as opposed to more urban regions further north. This would be a relative difference, however. Urbanized areas are likely to have higher levels of fragmentation due to increased development. While connectivity may potentially be less of an issue in the southern agricultural/rural areas, that is not to say these areas may not also face habitat connectivity issues such as conversion of riparian areas for agriculture, or that there are not agricultural landscapes with fragmented forest patches. In these cases, the implementation of corridors (such as hedgerows) may be recommended as a conservation tool to foster connectivity [47]. The establishment of WFCEs 
might help in this regard. Lastly, public access was only required on $3 \%$ of total easements. With the easements that required public access, each included an educational component where visitors could enter the property to learn about natural resource management in the area. Without the presence of these educational programs, it is probable that these easements would not have the public access requirement as it is relatively rare to require public access on most CEs [48].

An intriguing part of this investigation is the revelation of types of land frequently conserved in WFCEs. While limited to the state of Georgia, several clear patterns were evident. Wildlife food plots were encountered with the greatest frequency (but not area, since they are generally small). Given that hunting is a common recreational activity, this result was not surprising. The second most common land use type found was bottomland hardwoods. Given the high ecological importance of this land use type, its pervasiveness among WFCEs supports research showing that CEs are generally located in areas critical to ecosystem function [44]. This is further supported by the prevalence of other high-value ecosystems, such as mesic hardwoods, natural pines, and bogs/sinks. Each of these land use types support a wide variety of ecosystem functions and have seen their range curtailed by encroaching development. WFCEs permanently protect these land use types, providing support for the ability of CEs to protect vulnerable landscapes from development [26,49].

Planted pines occurred on a high proportion of the WFCEs examined. Approximately $78 \%$ of all WFCEs had this land use present. In these planted pine areas, common silvicultural practices such as herbicide/fertilizer application, thinning, and clearcutting were all generally available. We suspect that these areas would be under similar management regimes as those on unencumbered properties. This, along with the relatively mild level of area restrictions encountered, suggests that timber production is not significantly impacted by WFCEs [26]. Under these conditions, WFCE owners would maintain the ability to derive timber income from their properties.

The relation between easement themes and land use types largely reflected the patterns of easement themes. There was not a large difference among land uses for most themes. However, the relative importance of the themes of protecting endangered/threatened species and maintaining soil productivity did not follow this general pattern. The theme of protecting endangered/threatened species was encountered on $85 \%$ of all WFCEs, but only was present at around $30 \%-40 \%$ among all land use types. This may indicate that property owners and conservation agencies do not consider the presence of certain land use types as a determining factor for wildlife protection. Potentially, other factors such as the size of conserved area or region in which an easement is located, may be considered more important. Alternatively, as easements permanently restrict development potential, their establishment may be sufficient to provide wildlife protection in conserving areas that are at risk of development.

Conversely, maintaining soil productivity was encountered with approximately $80 \%-90 \%$ frequency among all land use types. This was surprising given that this theme was only encountered on $44 \%$ of all easements examined. This may be an indication that these land use types are particularly beneficial to maintaining soil productivity. However, given the percentage was relatively constant among all land types, other factors such as regional characteristics are likely to be at play.

WFCEs provide multiple opportunities for recreational activities in addition to their conservation and income preserving properties [50]. The WFCEs examined in this study had largely similar components. Hunting, fishing, hiking, camping, all-terrain vehicle use, and horseback riding were all highly prevalent as permitted activities. Watersports were less common; however, this is largely a function of select WFCEs lacking suitable amenities for this activity. Not all WFCEs had sufficiently large bodies of water present for this recreational opportunity to be viable. The wide availability of recreational opportunities found on these WFCEs likely relates to the interests of the landowners. Many landowners interested in conservation are likely to be older, white, male, have a higher educational attainment, and have a high desire for outdoor recreation activity [51]. Conservation-minded landowners are also highly likely to belong to some environmental conservation organizations [52] and are more likely to visit national parks than others [53]. Thus, the prevalence of recreational 
opportunities on WFCEs could be considered a result of landowners who are much more likely to be outdoor enthusiasts. As these recreational activities do not tend to adversely impact the conservation value of the easement properties, restrictions on their availability should and were found to be minimal in most cases.

Next, the hydrological features present on WFCEs lined up well with the types of recreation opportunities available. WFCEs generally had some form of creek or stream located on site. Ponds were common and often used in conjunction with recreational activities such as fishing or boating. Larger bodies of water such as lakes or rivers were less common. Where water features were present, watersports were generally available. The strong presence of hydrological features supports the finding that landowner of these WFCEs are likely to have riparian areas with some amount of bottomland hardwood present on site.

The forest management sections of the WFCEs revealed several key patterns. First, nearly all the WFCEs had some form of forest management plan required as part of the stipulations of the easement contract. This supports the findings of Song et al. [26] who found that adoption of CEs resulted in a greater likelihood of forest management plans being present. Additionally, most easements required registered foresters and/or certified wildlife biologists to compose these management plans. This result is in line with findings indicating these plans generally have some degree of natural resource professional oversight $[24,27,54]$. The length of these forest management plans varied in duration. However, of the WFCEs that reported a specific time frame, 15 years was the most common time horizon for a forest plan. Given that WFCEs largely conserve land in perpetuity, it is interesting that plans involving WFCEs would integrate long-term objectives into time horizons more typical of tactical plans.

Permissible forest management activities on WFCEs were relatively unsurprising. The forest management practices of clearcutting, thinning, selection cutting, prescribed burning, herbicide or fertilizer application, and exotic/invasive removals were all readily practiced on WFCEs. These activities were permissible on over $90 \%$ of all WFCEs investigated. These results support findings that conservation organizations usually give low priority to restricting many silvicultural activities on WFCEs [27,54]. Adding to this, other studies have concluded that management is not significantly restricted on CEs [26,55].

Further illustrating this point, the majority of WFCEs investigated had none to mild harvest restrictions. Approximately $62 \%$ of WFCEs had restrictions on less than $25 \%$ of easement area, while around $88 \%$ had restrictions on less than $50 \%$. The average size of restricted areas on WFCEs was $26 \%$ of total easement area. While this may seem to constitute a significant portion of potential harvest area, it is important to consider what areas are being restricted. Most restricted special natural areas consisted of hardwood bottoms along creeks or streams that would typically not be actively managed. In traditional forest management practices, many of these areas are already restricted in streamside management zones. Traditionally, buffers of 40-100 feet around streams are maintained from which timber harvesting is limited [46]. While these areas are restricted in easement contracts, they would likely face similar restrictions on nonencumbered property as well.

Forest management restrictions did not differ a great deal according to WFCE size category. The proportions of easements possessing a special natural area restriction was relatively consistent among size categories. Likewise, the percentage of area taken up by special natural areas generally was between $20 \%$ and $30 \%$ across all categories. Restrictions on clearcut size, availability, residual basal area, and grade restriction were relatively similar across size classes. Overall, these results support the notion that WFCEs are an effective tool for conserving forestland without placing undue burden on landowners and the characteristics of WFCEs are likely to be similar regardless of size.

Lastly, it is important to consider the relationship between the forest management activities performed in an area and their impact on biodiversity. Themes of wildlife and habitat protection were highly prevalent among these easements. However, management restrictions overall can be considered somewhat mild. There are likely to be some tradeoffs associated with increased management 
activity; however, the effects of WFCEs need to be taken as a whole. One of the primary threats to wildlife protection is habitat loss. This is frequently encountered when forested areas are converted to agricultural or development uses [56]. As WFCEs permanently restrict the development potential of an area, and often restrict the use of a property to its current land uses, they help address this issue. Further, these managed forest areas can buffer adjacent forested areas, potentially serving as corridors to increase habitat area [57].

Additionally, the management activity performed on forestland will have different effects on wildlife. Common silvicultural practices often increase early successional habitat, creating a mixture of stand ages when conducted near other forestland. This increases habitat diversity which can equate to an increase in overall biodiversity. Other practices such as prescribed burning can help replicate pine savanna conditions which are crucial habitats to threatened species such as the gopher tortoise or northern bobwhite quail (Colinus virginianus) [58,59]. The use of chemical herbicides can also be beneficial for biodiversity by modifying forest structure and controlling invasive species [58]. Further, modern herbicides have been demonstrated to be selective to plant pathways, pose little threat to humans or wildlife, do not bioaccumulate, and have limited short term effects that do not persist long term in the environment [60]. Conversely, increased forest management activity can also negatively impact select wildlife species as well. Intensive forest management often removes habitat features such as snags, downed woody debris, and understory vegetation. This can limit important habitat features and reduce terrestrial biodiversity. In particular, interior forest species may be negatively affected by increased forest heterogeneity resulting from silvicultural practices [56].

As a result, the effects of forest management on WFCES on wildlife will likely be variable. Certain species will benefit from the increased/maintained management, while others may be negatively impacted. Research has indicated that forest management activity with multiple strategies that enhance connectivity, heterogeneity, and stand complexity while maintaining aquatic integrity can increase the likelihood of suitable habitat provision for many species [61]. The WFCEs examined in this study meet many of these requirements. These WFCEs contain a variety of land use types, all adhere to forestry best management practices for water quality, require protection of special natural areas, and permanently protect land potentially at risk of development. Thus, when viewed in the context of their cumulative impact, they should likely be considered a net positive for both wildlife protection and forest management.

\section{Conclusions}

WFCEs in Georgia largely demonstrate an embodiment of the two main objectives of this property type, active forest management and conservation. Forest management practices are readily available to owners of WFCEs. While some restrictions on harvestable areas are likely to be present, they should not be considered a significant barrier towards continued forest management for producing income. Restrictions are often structured towards preventing development and maintaining sustainable forest management practices. Specifically, the WFCEs in this study tend to address both the sustainability of production and the sustainability of ecosystems, ensuring that certain areas are conserved in a nondegraded state [62]. Wildlife and habitat protection are also frequently provided with this easement type with forest management having potentially variable effects on these themes. To enhance their provision, owners of WFCEs should look to supplement forest management plans with wildlife management plans where possible, vary silvicultural prescriptions, and protect critical habitat zones [57].

Hence, WFCEs represent a viable option for continued forestland management while simultaneously reducing property tax pressure. Enforcement of easement contracts is generally left to third parties outside the grantor or grantee of an easement. These parties have the ability to enforce the terms of the easement and can bring a suit against the grantor if he/she fails to continue to meet these terms [45]. As such, grantors have a strong interest in ensuring that the conservation standards set forth in the easement contact continue to be met. Their establishment also serves to protect high quality habitats 
with important ecological functions. Moving forward, future research could use a similar analysis to the one employed in this paper to examine other WFCE structures in states other than Georgia. States located in the southeastern USA are likely to have similar political, cultural, social, and climatic characteristics. However, states located in the northeastern, mid-western, and western USA may differ due to the significant difference in land ownership profile.

Author Contributions: Conceptualization, T.R. and B.M.; methodology, T.R. and B.M.; software, T.R.; validation, T.R., B.M., J.S., P.B., and S.F.; formal analysis, T.R.; investigation, T.R.; resources T.R.; data curation, T.R.; writing-original draft preparation, T.R. and B.M.; writing_review and editing, T.R., B.M., J.S., P.B., and S.F.; visualization, T.R.; supervision, B.M.; project administration, T.R. and B.M.; funding acquisition, B.M., J.S., and P.B. All authors have read and agree to the published version of the manuscript.

Funding: This research was funded by USDA NIFA grant 2015-10780.

Acknowledgments: Special thanks to the Georgia Forestry Commission, Georgia Department of Natural Resources, and Georgia-Alabama Land Trust for providing easement information for this study.

Conflicts of Interest: The authors declare no conflict of interest. The funders had no role in the design of the study; in the collection, analyses, or interpretation of data; in the writing of the manuscript, or in the decision to publish the results.

\section{References}

1. GFC. Sustainability Report for Georgia's Forests: January 2019; Georgia Forestry Commission: Macon, GA, USA, 2019.

2. Enterprise Innovation Institute. 2018 Economic Benefits of the Forest Industry in Georgia; Georgia Institute of Technology: Atlanta, GA, USA, 2018.

3. Moore, R.; Williams, T.; Rodriguez, E.; Hepinstall-Cymmerman, J. Quantifying the Value of Non-Timber Ecosystem Services from Georgia's Private Forests; Georgia Forestry Foundation: Forsyth, GA, USA, 2011.

4. Wear, D.N.; Greis, J.G. The Southern Forest Futures Project: Summary Report; USDA-Forest Service, Southern Research Station: Asheville, NC, USA, 2012; pp. 1-54.

5. Zhang, Y.Q.; Zhang, D.W.; Schelhas, J. Small-scale non-industrial private forest ownership in the United States: Rationale and implications for forest management. Silva Fenn. 2005, 39, 443-454. [CrossRef]

6. Haines, A.L.; Kennedy, T.T.; McFarlane, D.L. Parcelization: Forest change agent in northern Wisconsin. J. For. 2011, 109, 101-108.

7. Land Trust Alliance. Conservation Options. Available online: https://www.landtrustalliance.org/what-youcan-do/conserve-your-land/conservation-options (accessed on 19 February 2020).

8. Yin, G. A Comparative Analysis of Industrial Timberland Property Taxation in the US South; University of Georgia: Athens, GA, USA, 2002.

9. Cushing, T.L.; Newman, D. Analysis of relative tax burden on nonindustrial private forest landowners in the southeastern United States. J. For. 2018, 116, 228-235. [CrossRef]

10. Zhang, W.; Mei, B.; Izlar, R.L. Impact of forest-related conservation easements on contiguous and surrounding property values. For. Policy Econ. 2018, 93, 30-35. [CrossRef]

11. Polyakov, M.; Zhang, D. Property tax policy and land-use change. Land Econ. 2008, 84, 396-408. [CrossRef]

12. Rosenblatt, R.A. Conservation easements: Permanent shields against sprawl. J. For. 2002, 100, 8-12.

13. Merenlender, A.M.; Huntsinger, L.; Guthey, G.; Fairfax, S.K. Land trusts and conservation easements: Who is conserving what for whom? Conserv. Biol. 2004, 18, 65-75. [CrossRef]

14. Chamblee, J.F.; Colwell, P.F.; Dehring, C.A.; Depken, C.A. The effect of conservation activity on surrounding land prices. Land Econ. 2011, 87, 453-472. [CrossRef]

15. Cheever, F.; McLaughlin, N.A. An introduction to conservation easements in the United States: A simple concept and a complicated mosaic of law. J. Law Prop. Soc. 2015, 1, 107-186.

16. Owley, J. The enforceability of exacted conservation easements. Vt. Law Rev. 2011, 36, 261-302.

17. Mitchell, P. Protecting the Future Forever: Why Perpetual Conservation Easements Outperform Term Easements; Land Use Clinic Paper 10; University of Georgia School of Law: Athens, GA, USA, 2006.

18. Chang, K. National Land Trust Census Report: Our Common Ground and Collective Impact; Land Trust Alliance: Washington, DC, USA, 2015. 
19. National Conservation Easement Database. Easement Holder Profile. Available online: https://www. conservationeasement.us/eholderprofile/ (accessed on 28 September 2019).

20. Yoo, J.; Ready, R. The impact of agricultural conservation easement on nearby house prices: Incorporating spatial autocorrelation and spatial heterogeneity. J. For. Econ. 2016, 25, 78-93. [CrossRef]

21. Mittal, J. Value capitalization effect of protected properties: A comparison of conservation easement with mixed-bag open spaces. J. Sustain. Real Estate 2014, 6, 23-26.

22. Geoghegan, J.; Lynch, L.; Bucholtz, S. Capitalization of open spaces into housing values and the residential property tax revenue impacts of agricultural easement programs. Agric. Resour. Econ. Rev. 2003, 32, $33-45$. [CrossRef]

23. Polasky, S.; Nelson, E.; Lonsdorf, E.; Fackler, P.; Starfield, A. Conserving species in a working landscape: Land use with biological and economic objectives. Ecol. Appl. 2005, 15, 1387-1401. [CrossRef]

24. Rissman, A.R.; Lozier, L.; Comendant, T.; Kareiva, P.; Kiesecker, J.M.; Shaw, M.R.; Merenlender, A.M. Conservation easements: Biodiversity protection and private use. Conserv. Biol. 2007, 21, 709-718. [CrossRef]

25. Farmer, J.R.; Meretsky, V.; Knapp, D.; Chancellor, C.; Fischer, B.C. Why agree to a conservation easement? Understanding the decision of conservation easement granting. Landsc. Urban Plan. 2015, 138, 11-19. [CrossRef]

26. Song, N.; Aguilar, F.X.; Butler, B.J. Conservation easements and management by family forest owners: A propensity score matching approach with multi-imputations of survey data. For. Sci. 2014, 60, 298-307. [CrossRef]

27. Mortimer, M.J.; Richardson, J.J.; Huff, J.S.; Haney, H.L. A survey of forestland conservation easements in the United States: Implications for forestland owners and managers. Small-Scale For. 2007, 6, 35-48. [CrossRef]

28. Georgia State Properties Commission. Building Land \& Lease Inventory of Property. Available online: https://www.realpropertiesgeorgia.org/ (accessed on 11 December 2019).

29. GSCCCA. The Clerks Authority. Available online: https://www.gsccca.org/search (accessed on 14 February 2020).

30. TMS. Quarterly Market Bulletin: 3rd Quarter 2019; TimberMart-South: Athens, GA, USA, 2019.

31. Silge, J.; Robinson, D. Tidytext: Text Mining and Analysis Using Tidy Data Principles in R. J. Open Source Softw. 2016, 1, 1-3. [CrossRef]

32. Georgia Department of Natural Resources. Georgia State Wildlife Action Plan; Department of Natural Resources: Social Circle, GA, USA, 2015.

33. Capon, S.; Chambers, L.; Mac Nally, R.; Naiman, R.; Davies, P.; Marshall, N.; Pittock, J.; Reid, M.; Capon, T.; Douglas, M.; et al. Riparian ecosystems in the 21st century: Hotspots for climate change adaptation? Ecosystems 2013, 16, 359-381. [CrossRef]

34. Jenkins, W.A.; Murray, B.C.; Kramer, R.A.; Faulkner, S.P. Valuing ecosystem services from wetlands restoration in the Mississippi Alluvial Valley. Ecol. Econ. 2010, 69, 1051-1061. [CrossRef]

35. EPA. Bottomland Hardwoods. Available online: https://www.epa.gov/wetlands/bottomland-hardwoods (accessed on 14 February 2020).

36. King, S.L.; Keim, R.F. Hydrologic modifications challenge bottomland hardwoodforest management. J. For. 2019, 117, 504-514.

37. Schweitzer, C.J. History, highlights, and perspectives of southern upland hardwood silviculture research. J. For. 2019, 117, 55-64. [CrossRef]

38. Clabo, D.; Peairs, S.; Dickens, D. Managing Upland Loblolly Pine-Hardwood Forest Types for Georgia Landowners; Warnell School of Forestry and Natural Resources: Athens, GA, USA, 2019.

39. Kroeger, A.J.; Moorman, C.E.; Lashley, M.A.; Chitwood, M.C.; Harper, C.A.; DePerno, C.S. White-tailed deer use of overstory hardwoods in longleaf pine woodlands. For. Ecol. Manag. 2020, 464, 1-14. [CrossRef]

40. Brandeis, T.J.; McCollum, J.M.; Hartsell, A.J.; Brandeis, C.; Rose, A.K.; Oswalt, S.N.; Vogt, J.; Marcano Vega, H. Georgia's Forests; U.S. Forest Service Southern Research Station: Asheville, NC, USA, 2014.

41. Georgia Department of Natural Resources. Species Fact Sheets. Available online: https://georgiawildlife. com/species (accessed on 14 February 2020).

42. Palik, B.J.; Golladay, S.W.; Taylor, B.W. Invertebrate communities of forested limesink wetlands in southwest Georgia, USA: Habitat use and influence of extended inundation. Wetlands 1997, 17, 383-393.

43. Kreye, M.M.; Adams, D.C.; Escobedo, F.J. The value of forest conservation for water quality protection. Forests 2014, 5, 862-884. [CrossRef] 
44. Kiesecker, J.M.; Comendant, T.; Grandmason, T.; Gray, E.; Hall, C.; Hilsenbeck, P.; Kareiva, P. Conservation easements in context: A quantitative analysis of their use by The Nature Conservancy. Front. Ecol. Environ. 2007, 5, 125-130. [CrossRef]

45. Tesini, D. Working forest conservation easements. Urban Lawyer 2009, 41, 359-375.

46. GFC. Georgia's Best Management Practices for Forestry; Georgia Forestry Commission: Macon, GA, USA, 2019.

47. Beier, P.; Noss, R.F. Do habitat corridors provide connectivity? Conserv. Biol. 1998, 12, 1241-1252. [CrossRef]

48. Miskowiak, D.; Stoll, L. Planning Implementation Tools: Conservation Easements; Center for Land Use Education, University of Wisconsin Stevens Point: Wasau, WI, USA, 2006.

49. Braza, M. Effectiveness of conservation easements in agricultural regions. Conserv. Biol. 2017, 31, 848-859. [CrossRef]

50. Sundberg, J.O. Using conservation easements to protect open space: Public policy, tax effects, and challenges. J. Prop. Tax Assess. Adm. 2013, 10, 5-20.

51. Farmer, J.R.; Brenner, J.C.; Drescher, M.; Dickinson, S.L.; Knackmuhs, E.G. Perpetual private land conservation: The case for outdoor recreation and functional leisure. Ecol. Soc. 2016, 21, 765-780. [CrossRef]

52. Farmer, J.R.; Chancellor, C.; Brenner, J.; Whitacre, J.; Knackmuhs, E.G. To ease or not to ease: Interest in conservation easements among landowners in Brown County, Indiana. Prof. Geogr. 2016, 68, 584-594. [CrossRef]

53. Farmer, J.R.; Ma, Z.; Drescher, M.; Knackmuhs, E.G.; Dickinson, S.L. Private landowners, voluntary conservation programs, and implementation of conservation friendly land management practices. Conserv. Lett. 2017, 10, 58-66. [CrossRef]

54. Rissman, A.R. Rethinking property rights: Comparative analysis of conservation easements for wildlife conservation. Environ. Conserv. 2013, 40, 222-230. [CrossRef]

55. Pocewicz, A.; Kiesecker, J.M.; Jones, G.P.; Copeland, H.E.; Daline, J.; Mealor, B.A. Effectiveness of conservation easements for reducing development and maintaining biodiversity in sagebrush ecosystems. Biol. Conserv. 2011, 144, 567-574. [CrossRef]

56. Miller, D.A.; Wigley, T.B.; Miller, K.V. Managed forests and conservation of terrestrial biodiversity in the southern United States. J. For. 2009, 107, 197-203.

57. Carnus, J.M.; Parrotta, J.; Brockerhoff, E.; Arbez, M.; Jactel, H.; Kremer, A.; Lamb, D.; O'Hara, K.; Walters, B. Planted forests and biodiversity. J. For. 2006, 104, 65-77.

58. Jones, J.D.J.; Chamberlain, M.J. Efficacy of herbicides and fire to improve vegetative conditions for northern bobwhites in mature pine forests. Wildl. Soc. Bull. 2004, 32, 1077-1084. [CrossRef]

59. Greene, R.E.; Iglay, R.B.; Evans, K.O.; Wigley, T.B.; Miller, D.A. Estimating capacity of managed pine forests in the southeastern U.S. to provide open pine woodland condition and gopher tortoise habitat. For. Ecol. Manag. 2019, 432, 200-208. [CrossRef]

60. Miller, D.A.; Wigley, T.B. Introduction: Herbicides and forest biodiversity. Wildl. Soc. Bull. 2004, 32, 1016-1019. [CrossRef]

61. Lindenmayer, D.B.; Margules, C.R.; Botkin, D.B. Indicators of biodiversity for ecologically sustainable forest management. Conserv. Biol. 2000, 14, 941-950. [CrossRef]

62. Bettinger, P.; Boston, K.; Siry, J.P.; Grebner, D.L. Forest Management and Planning, 2nd ed.; Academic Press: London, UK, 2017; p. 331.

(C) 2020 by the authors. Licensee MDPI, Basel, Switzerland. This article is an open access article distributed under the terms and conditions of the Creative Commons Attribution (CC BY) license (http://creativecommons.org/licenses/by/4.0/). 